The Impact of Transitory Losses on Firms' Corporate Governance Structure

Shereen Mohamed Abd El-Fattah Mahmoud

\title{
The Impact of Transitory Losses on Firms' Corporate Governance Structure
}

\section{Shereen Mohamed Abd El-Fattah Mahmoud}

\section{Abstract:}

This research investigates the impact of one major form of underperformance in companies, the reporting of a transitory losses, on post-changes occurring in the corporate governance structure $(\mathrm{CG})$ of these companies. The research uses a combined sample of 52 firms listed in the Egyptian Stock Exchange (EGX) during the period from 2014 to 2017. A loss sample of 26 firms is matched to a profit sample of 26 firms based on industry and firm size to isolate the loss situation and control for industry characteristics. Using confirmatory factor analysis and difference-in-differences (DID) analysis, the findings indicate that there is a significant impact of the reporting of a transitory loss on changes occurring in the corporate governance structure of loss firms in the period following the loss, but these changes are not significantly different from those made by the profit firms.

Keywords: Transitory Loss, Corporate Governance Structure, Board Composition, Ownership Structure 
The Impact of Transitory Losses on Firms' Corporate Governance Structure

Shereen Mohamed Abd El-Fattah Mahmoud

\section{Introduction:}

A firm's profitability is one of the main concerns for the management, since business organizations depend on profitability for their existence, growth and survival (Menicucci $\&$ Paolucci, 2016), and it's also one of the main factors that contribute to the satisfaction of investors and the sustainability of the company as a whole (Alarussi \& Alhaderi, 2018). The profitability of the firm represents a significant indicator for its market value. The management desires to maximize the firm's profits and sustain consistent earnings to avoid fluctuations in its stock prices (Nanda \& Panda, 2018).

On the other hand, corporate governance has been one of the key research topics in the business discipline, and its importance increased even more in the recent decades, after a series of worldwide corporate breakdowns due to fraud and other scandals which caused huge bankruptcies and put investors and shareholders into doubt. And as a result, "the response of Congress and regulators to this crisis of confidence was to impose new corporate governance requirements on public companies such as the SarbanesOxley Act of 2002" (Baker \& Powell, 2009, p. 83).

Corporate governance was defined as a mechanism that provides a guarantee that investors in corporations get a return on their investments, which means that corporate governance is 
The Impact of Transitory Losses on Firms' Corporate Governance Structure

Shereen Mohamed Abd El-Fattah Mahmoud

a way to guide managers in directing the corporation (Srivastava et al., 2018). Internal governance mechanisms include, among others, the board of directors' structure, segregation of control, gender diversity; external mechanisms include the labor market for managers, government regulations and other external mechanisms (Damak, 2013).

The corporate governance structure plays a role in creating a balance between the existing conflict of interests between principals and agents. This conflict arises due to the fact that corporate managers will try to act in their own best interest, regardless of their principals' (shareholders') benefit which might be contradicted with the former's. And as indicated by L'Huillier (2014), corporate governance mechanisms "keep agents in check" and control their use of accounting discretion, and these mechanisms all contribute to a firm's corporate governance structure.

It is suggested that one way to measure the degree to which corporate governance mechanisms are effective, is when a firm is underperforming (Mulcahy, 2014). As discussed by Mulcahy, one extreme form of underperformance in corporations is incurring an unexpected loss after a period of reporting profit. This loss is considered a negative event and a "shock" for the firm, therefore a "transitory loss" is used to refer to the situation where a firm 
The Impact of Transitory Losses on Firms' Corporate Governance Structure

Shereen Mohamed Abd El-Fattah Mahmoud

reports an unexpected loss after at least two consecutive years of reporting profits.

\section{Background and Hypotheses Development:}

The number of studies investigating more specific features of corporate governance is increasing, especially how already-existing corporate governance structures affect the overall performance of the firm. However, little research has been done to investigate firm-level changes of corporate governance in response to the occurrence of different forms of financial failure and shock events.

One reason might pertain to the notion that corporate governance is sticky and not susceptible to quick changes over short periods of time, in addition to being uniform in accordance with different governance codes (Beasley et al., 2010). Besides, the primary focus of governance studies concerning internal governance mechanisms is usually directed towards the characteristics of the firm's board of directors and its ownership structure (Bebchuk \& Weisbach, 2010).

Most of the literature that addressed corporate governance changes after shock events is consistent and provides evidence of improvements occurring in the firm's corporate governance structure following the occurrence of a shock event or periods of bad performance. Some of the 
The Impact of Transitory Losses on Firms' Corporate Governance Structure

Shereen Mohamed Abd El-Fattah Mahmoud

empirical results show increases in the size, independence and expertise of its board members, as well as an increased number of meetings. Furthermore, less inside board members and less CEO duality exist in firms and banks following periods of bad financial performance, losses, fraud and negative media reports (Arora \& Sharma, 2015; Mulcahy \& Donnelly, 2015; Nasir et al., 2019; Okhmatovskiy \& Shin, 2019; Younas et al., 2019; Fernández et al., 2020).

On the other hand, very few studies find no evidence of changes in the corporate governance structure following shock events, such as the findings of Eshagniya $\&$ Salehi (2017) that suggest no association between financial restatements and post-period changes in corporate governance, which is also consistent with Fernández et al. (2020) in the period following the 2008 financial crisis.

Following the occurrence of shock events, the firm's response strategies to crises become significantly important (Ferretti et al., 2015). There is no doubt that suffering a transitory loss is one extreme case of underperformance, therefore it is critical to investigate the response of internal corporate governance mechanisms and how they are modified after the reporting of a transitory loss. Accordingly, and due to the lack of empirical results 
The Impact of Transitory Losses on Firms' Corporate Governance Structure

Shereen Mohamed Abd El-Fattah Mahmoud

linking losses and corporate governance, the following two null hypotheses can be constructed:

$H_{0} 1$ : The reporting of a transitory loss has no impact on the board of directors' composition of the firm.

$\mathrm{H}_{0}$ 2: The reporting of a transitory loss has no impact on the ownership structure of the firm.

\section{Methodology:}

\subsection{Data Sources and Sample Selection}

Two sets of data are gathered; financial data (transitory loss), and non-financial data (corporate governance). Secondary data is obtained from the published financial statements of the companies listed in the Egyptian Stock Exchange, as well as the managements' annual reports and disclosure reports from the Egyptian Stock Exchange website, Egypt for Information Dissemination (EGID) and different companies' websites.

To test the developed hypotheses, two separate but matched data samples, a transitory loss sample and a matched profit sample are collected. The first sample consists of all the companies which reported a transitory loss. The second sample is a matched control sample of profitable firms based on industry and firm size. The research investigation period for the overall combined sample ranges from 2014 to 2017. 
The Impact of Transitory Losses on Firms' Corporate Governance Structure

Financial service companies and banks are excluded due to their specialized accounting measurement methods.

Therefore, the final two samples of the research consist of a total of 52 listed companies in the Egyptian Stock Exchange, divided into 26 loss firms matched against 26 profit firms from 2014 to 2017, resulting in a total of 208 firm-year observations.

\subsection{Variables Construction and Measurement}

\subsubsection{Transitory Loss:}

The independent variable of this research is transitory loss. Transitory loss is defined as the situation in which a firm reports negative net income that was preceded and followed by at least two consecutive years of reporting positive earnings.

The proxy used for transitory loss is reported negative net income after tax. In addition, it can't be just any random negative net income, but it also has to be preceded and followed by the firm reporting positive earnings for at least two consecutive years.

\subsubsection{Corporate Governance Structure:}

The dependent variable of this research is corporate governance structure. Following previous corporate 
The Impact of Transitory Losses on Firms' Corporate Governance Structure

governance studies (Alfraih, 2017; Utama et al., 2017; Karim et al., 2019; Zhou, 2020), this research paper focuses on two corporate governance internal mechanisms and excludes external mechanisms that are outside the control of the management, which are: Board of directors' composition and ownership structure.

The most commonly used proxies in the literature to measure board composition and ownership structure are employed by the researcher. A description of each proxy is detailed in Table No. (1); Panels (A) and (B).

\section{Table No. (1): Description of Corporate Governance Variables}

Panel (A): Board Composition Proxies

\begin{tabular}{|l|l|}
\hline \multicolumn{1}{|c|}{ Proxy } & \multicolumn{1}{c|}{ Description } \\
\hline Board Size (Bsize) & The number of board members. \\
\hline $\begin{array}{l}\text { \%Non-executive Directors } \\
\% \text { NEDs })\end{array}$ & $\begin{array}{l}\text { The proportion of non-executive directors on the } \\
\text { board, calculated by dividing the number of non- } \\
\text { executive directors by the overall board size. }\end{array}$ \\
\hline $\begin{array}{l}\text { \%Independent Non-executive } \\
\text { Directors (\%INDs) }\end{array}$ & $\begin{array}{l}\text { The proportion of independent, non-executive } \\
\text { directors on the board, calculated by dividing the } \\
\text { number of independent non-executive directors by the } \\
\text { overall board size. }\end{array}$ \\
\hline
\end{tabular}




\begin{tabular}{|l|l|}
\hline $\begin{array}{l}\text { Non-executive Chairman } \\
\text { (NEC) }\end{array}$ & $\begin{array}{l}\text { Whether the chairman of the board is non-executive, } \\
\text { takes the value of } 1 \text { if true, } 0 \text { otherwise. }\end{array}$ \\
\hline $\begin{array}{l}\text { Independent Non-executive } \\
\text { Chairman (INEC) }\end{array}$ & $\begin{array}{l}\text { Whether the chairman of the board is independent } \\
\text { non-executive, takes the value of } 1 \text { if true, } 0 \text { otherwise. }\end{array}$ \\
\hline \%Female Directors (\%FEM) & $\begin{array}{l}\text { Proportion of female directors on the board, calculated } \\
\text { by dividing the number of female directors by the } \\
\text { overall board size. }\end{array}$ \\
\hline
\end{tabular}

\begin{tabular}{|l|l|}
\hline \multicolumn{1}{|c|}{ Proxy } & \multicolumn{1}{c|}{ Description } \\
\hline $\begin{array}{l}\text { \%Shares Held by All } \\
\text { Directors (\%TotD) }\end{array}$ & The proportion of firm shares held by all directors. \\
\hline $\begin{array}{l}\text { \%Shares Held by Top } \\
\text { Director (\%TopD) }\end{array}$ & $\begin{array}{l}\text { The proportion of firm shares held by the top director (by } \\
\text { number of shares owned). }\end{array}$ \\
\hline $\begin{array}{l}\text { \%Shares Held by All } \\
\text { Institutional Investors } \\
\text { (\%TotInv) }\end{array}$ & $\begin{array}{l}\text { The proportion of shares held by all firm's institutional } \\
\text { investors. }\end{array}$ \\
\hline $\begin{array}{l}\text { \%Shares Held by Top } \\
\text { Institutional Investor } \\
\text { (\%TopInv) }\end{array}$ & $\begin{array}{l}\text { The proportion of firm shares held by the top institutional } \\
\text { investor (by number of shares owned). }\end{array}$ \\
\hline $\begin{array}{l}\text { \%Shares Held by All } \\
\text { Shareholders With Shares } \\
\text { of 5\% or More } \\
\text { (\%TotBlock) }\end{array}$ & $\begin{array}{l}\text { The proportion of shares held by all firm's shareholders in } \\
\text { amounts > 5\%. }\end{array}$ \\
\hline
\end{tabular}

\footnotetext{
Source: done by the researcher.
} 
The Impact of Transitory Losses on Firms' Corporate Governance Structure

Shereen Mohamed Abd El-Fattah Mahmoud

\subsection{The Model Used}

Following Mulcahy \& Donnelly (2015), to test the impact of transitory loss on firms' corporate governance structure $\left(\mathrm{H}_{0} 1 \& \mathrm{H}_{\mathrm{o}} 2\right)$, the following difference-in-difference equation model is used:

$$
\Delta G O V=\beta+\delta D_{\text {LOSS }, \mathrm{t}}+\theta \mathrm{LEV}_{\mathrm{t}}+\varepsilon
$$

\section{Where:}

$\triangle G O V=$ change in each of the corporate governance variables, board and ownership separately during the test period.

$\beta=$ change in the corporate governance structure for the profit sample.

$\delta=$ change in the corporate governance structure between the loss sample and the control sample.

$(\beta+\delta)=$ change in the corporate governance structure for the loss sample.

$D_{\text {LOSS }, \mathrm{t}}=$ transitory loss, a dummy variable that takes the value of 1 for the loss sample; 0 for control sample.

$\mathrm{LEV}_{\mathrm{t}}=$ firm leverage, measured by total debt divided by total equity. $\varepsilon=$ error term. 
The Impact of Transitory Losses on Firms' Corporate Governance Structure

Consistent with Okhmatovskiy \& Shin (2019) leverage is also used as a control variable, since firms' corporate governance structure might be affected if the firm relies heavily on debt, therefore leverage is employed as the firm's debt-to-equity ratio.

To capture changes in the corporate governance structure of the firm, the difference-in-differences (DID) method is applied. The loss event occurs in the year ( $t$ ), whereas pre-loss represents ( $\mathrm{t}-1)$ and post-loss is $(\mathrm{t}+1)$. To report any changes occurring in the CG structure of the firm, CG data must be collected in the year preceding the reporting of loss ( $t-1)$ and compared against the period following the loss reporting year $(t+1)$ in both the loss sample and control (profit) sample to test for the impact of the loss event.

\subsection{Statistical Analysis and Results}

\subsubsection{Descriptive Statistics:}

Table No. (2) reports the descriptive statistics for the variables of both the loss and profit samples combined, including mean, median, standard deviation, maximum, minimum, skewness and kurtosis for the variables of the study. The table shows all the variables of the CG model in both pre-loss and post-loss years combined $(t-1$ and $t+1)$. 
The Impact of Transitory Losses on Firms' Corporate Governance Structure Shereen Mohamed Abd El-Fattah Mahmoud

\section{Table No. (2): Descriptive Statistics of CG Model Variables for the Combined Sample, All Years.}

\begin{tabular}{|c|c|c|c|c|c|c|c|}
\hline Variable & Mean & Median & $\begin{array}{c}\text { Std. } \\
\text { Deviation }\end{array}$ & MAX & MIN & Skewness & Kurtosis \\
\hline Bsize & 7.922 & 7.000 & 3.030 & 17.000 & 4.000 & 1.048 & 0.797 \\
\hline \%NEDs & 0.683 & 0.714 & 0.204 & 1.000 & 0.000 & -0.996 & 1.146 \\
\hline \%INDs & 0.096 & 0.000 & 0.142 & 0.545 & 0.000 & 1.280 & 0.596 \\
\hline NEC & 0.183 & 0.000 & 0.387 & 0.714 & 0.000 & 1.656 & 0.752 \\
\hline INEC & 0.000 & 0.000 & 0.000 & 0.000 & 0.000 & 0.000 & 0.000 \\
\hline \%FEM & 0.117 & 0.100 & 0.138 & 0.971 & 0.000 & 1.280 & 1.739 \\
\hline$\%$ TotD & 0.492 & 0.469 & 0.274 & 0.912 & 0.018 & 0.037 & -1.190 \\
\hline \%TopD & 0.343 & 0.258 & 0.245 & 0.971 & 0.018 & 0.978 & -0.002 \\
\hline \%TotInv & 0.417 & 0.379 & 0.324 & 0.971 & 0.000 & 0.234 & -1.464 \\
\hline \%TopInv & 0.298 & 0.242 & 0.259 & 0.912 & 0.000 & 0.984 & 0.008 \\
\hline \% TotBlock & 0.618 & 0.643 & 0.229 & 1.000 & 0.249 & -0.357 & -0.650 \\
\hline Leverage & 1.279 & 0.728 & 1.949 & 13.857 & 0.0005 & 3.833 & 17.657 \\
\hline
\end{tabular}

*Descriptions of each variable are included in Table No. (1)

From the results of Table No. (2), it can be observed that on average, board sizes are relatively small with a mean of 7.92 and a reasonable spread of observations around the mean, with a standard deviation of 3.03, therefore the coefficient of variation is 0.38 .

Regarding non-executive directors, the centralization of $\%$ NEDs equals, on average, $68 \%$ of the total sample, which represents more than half the members of each board. It is 
The Impact of Transitory Losses on Firms' Corporate Governance Structure

Shereen Mohamed Abd El-Fattah Mahmoud

also noticed that at least one or more firms have all their members be non-executives. On the other hand, it can be observed that on average, $9.6 \%$ of the sample firms have independent members, which is relatively low.

The interpretation of NEC and INEC is also interesting. An average of $18.3 \%$ of chairmen are non-executive, which means that $81.7 \%$ of the sample firms have a dual chair and CEO. Another look at the independence of the chairman immediately shows that among 206 firm-year observations, zero board chairmen in both loss and profit samples were independent, and therefore this variable is excluded from the analysis. With regard to gender diversity, boards hold an average of $11.7 \%$ female directors, with a standard deviation of 0.138 . However, the maximum value of \%FEM is $97.1 \%$, indicating that at least one board has the majority of its directors be females.

Regarding director ownership, the results show a mean of $49.2 \%$ and a standard deviation of 0.274 , with the top director owning an average of $34.3 \%$ of the firm shares and a maximum of $97.1 \%$ of the firm's ownership. Moreover, institutional ownership also represents a mean of $41.7 \%$ and standard deviation of 0.324 , indicating concentrated ownership among few directors and institutional investors, consistent with the previous literature agreeing that Egyptian firms are characterized 
The Impact of Transitory Losses on Firms' Corporate Governance Structure

Shereen Mohamed Abd El-Fattah Mahmoud

by highly concentrated structures of ownership (Khlif et al., 2015; El-Diftar et al., 2017). Leverage has a mean of 1.279, which means that firms are struggling financially with high debt compared to their equity.

\subsubsection{Confirmatory Factor Analysis:}

Two corporate governance mechanisms are selected to form the overall CG structure of the firm, which are the board composition and ownership structure. Using each of these proxies individually to measure each one of these two constructs will not provide a clear picture of how these variables are combined to form the board composition and ownership structure of the firm and eventually, the overall CG structure. Moreover, the use of individual CG variables might lead to multi-collinearity among the variables.

Therefore, and consistent with prior CG literature that applies governance indices, factor analysis is used to combine the variables of each construct into two individual factors named Board and Ownership. This research applies confirmatory factor analysis (CFA) to verify the existence of a relationship between the observed CG variables introduced in Table No. (1) and their underlying latent constructs; Board and Ownership, based on the hypothesis that Panel (A) variables of Table No. (1) combine to form the board composition of the firm (with the exception of independent 
The Impact of Transitory Losses on Firms' Corporate Governance Structure

chairman which is excluded), whereas Panel (B) variables combine to form the ownership structure. The sample used for CFA is the combined loss and profit sample.

Table No. (3): Confirmatory Factor Analysis Model Results

\begin{tabular}{|c|c|c|c|c|}
\hline Factor & Variable & $\begin{array}{c}\text { Factor } \\
\text { loading }\end{array}$ & $\begin{array}{c}\text { Standard } \\
\text { Error }\end{array}$ & t-value \\
\hline \multirow{4}{*}{ Board } & Bsize & 0.45 & 0.12 & 3.87 \\
\cline { 2 - 5 } & \%NEDs & 1.08 & 0.22 & 4.81 \\
\cline { 2 - 5 } & \%INDs & -0.15 & 0.077 & -1.91 \\
\cline { 2 - 5 } & NEC & 0.26 & 0.090 & 2.89 \\
\cline { 2 - 5 } & \%FEM & 0.15 & 0.077 & 1.98 \\
\hline \multirow{4}{*}{ Ownership } & \%TotD & 0.93 & 0.058 & 16.11 \\
\cline { 2 - 5 } & \%TopD & 0.89 & 0.060 & 14.71 \\
\cline { 2 - 5 } & \%TotInv & 0.74 & 0.066 & 11.26 \\
\cline { 2 - 5 } & \%TopInv & 0.81 & 0.063 & 12.85 \\
\cline { 2 - 5 } & \%TotBlock & 0.81 & 0.063 & 12.74 \\
\hline
\end{tabular}

Table No. (3) reports the results of the CFA conducted on each of the CG variables. The Maximum Likelihood method was used. Factor loading values in CFA don't need a specific cutoff (acceptable) value as long as they are significant.

The factor loading values are a statistically significant function on both the first factor "board" and the second factor "ownership." The value of alpha is to accept statistical significance of 0.05 . In order to accept loadings on factors, the $\mathrm{t}$-value has to have a cutoff score equal to 1.96 or more. 
The Impact of Transitory Losses on Firms' Corporate Governance Structure

The results of Table No. (3) show that all CG variables report significant t-values of 1.96 or higher, except for $\%$ INDs with a t-value of -1.91 , therefore it should be excluded from the analysis and be analyzed separately. The rest of the variables: Bsize, \%NEDs, NEC, \%FEM significantly load on the first factor, board. Whereas: \% TotD, \%TopD, \%TotInv, \%TopInv, \%TotBlock significantly load on the second factor, ownership. Therefore, the results support the existence of significant relationships between the observed and latent variables.

\subsubsection{Multiple DID Regression Analysis and Discussion of Results:}

A multiple DID regression analysis of the CG model (equation 1) is conducted and the results are included in Table No. 4 as follows: 
The Impact of Transitory Losses on Firms' Corporate Governance Structure Shereen Mohamed Abd El-Fattah Mahmoud

Table No. (4): Multiple Regression Analysis of CG Model

$$
\Delta G O V=\beta+\delta D_{\text {LOSS }, \mathrm{t}}+\theta \mathrm{LEV}_{\mathrm{t}}+\varepsilon
$$

\begin{tabular}{|c|c|c|c|}
\hline $\begin{array}{c}\text { Independent } \\
\text { Variables }\end{array}$ & $\begin{array}{c}\text { Board } \\
\text { (t-value) }\end{array}$ & $\begin{array}{c}\text { Ownership } \\
\text { (t-value) }\end{array}$ & $\begin{array}{c}\text { \% INDs } \\
\text { (t-value) }\end{array}$ \\
\hline Intercept & 9.053 & 2.025 & 6.437 \\
& $(1.439)$ & $(5.042)$ & $(1.085)$ \\
\hline$D_{\text {LoSS }}$ & 0.051 & 0.272 & 0.032 \\
& $(-0.097)$ & $(1.435)$ & $(-0.099)$ \\
\hline LEV & -0.003 & 0.001 & -0.004 \\
& $(-0.883)$ & $(0.656)$ & $(-0.997)$ \\
\hline $\mathbf{n}$ & 52 & 52 & 52 \\
\hline $\mathbf{R}^{2}$ & $0.5 \%$ & $1.80 \%$ & $0.3 \%$ \\
\hline
\end{tabular}

Two-tailed P-values for Tests of Significance:

Intercept $+D_{\text {LOSS }, \mathrm{t}}=0.04$

(Board)

Intercept $+D_{\text {LOSS }, \mathrm{t}}=0.02$

(Ownership)

Intercept $+D_{\text {LOSS }}=0.04$

(\%INDs)

Table No. (4) reports the results of the multiple regression analysis of corporate governance changes in the combined sample of 52 firms, divided into 26 loss firms and 26 profit firms. The results of the multiple regression show that the corporate governance structure responds to the reporting of a transitory loss in the period following the loss, 
The Impact of Transitory Losses on Firms' Corporate Governance Structure

Shereen Mohamed Abd El-Fattah Mahmoud

as observed by the results of the two-tailed test of significance of Intercept $+D_{\text {LOSS, }}$ (changes of CG in the loss sample), with P-values of 0.04, 0.02 and 0.04 for Board, Ownership and \%INDs respectively, implying significant changes in each construct. This is consistent with the prior literature which showed evidence of CG changes following shock events.

Another look at the intercept values (changes of $\mathrm{CG}$ in profit sample) provides consistency with the results of the univariate analysis and indicates that profit firms applied significant changes to their ownership structure, with a positive t-value of 5.042, whereas Board and \%INDs were positive but insignificant (coefficient $=9.053$, t-value $=$ 1.439; coefficient $=6.437$, $\mathrm{t}$-value $=1.085$, respectively).

However, the main focus of this research paper is to investigate the significant changes in $\mathrm{CG}$ structure in response to transitory loss in the loss sample and the difference of these changes in comparison with the profit sample, therefore the coefficient of $D_{\text {LOSS }}$ (difference in differences of $\mathrm{CG}$ between loss and profit sample) represents the primary interest of this research paper. The results indicate that no significant changes occur in the Board, Ownership and \%INDs of loss firms with respect to the profit firms, with t-values in both Board and 
The Impact of Transitory Losses on Firms' Corporate Governance Structure

Shereen Mohamed Abd El-Fattah Mahmoud

Ownership of -0.097 and 1.435 respectively. The values of $\mathrm{R}^{2}$ indicate that both transitory loss and leverage account for only $0.5 \%, 1.8 \%$, and $0.3 \%$ of the changes in Board, Ownership, and \%INDs, respectively.

The interpretation of these results is that, although transitory loss firms applied modifications in their board composition and ownership structures, these modifications were positive but not significant in comparison with the profit firms. In other words, firms that reported a transitory loss had changes in their CG structure that weren't significantly different from the changes made in firms that didn't incur a loss. These results lead the researcher to conclude that CG changes weren't only limited to the reporting of transitory loss solely, but other mutual conditions between both samples were possibly a factor in the changes that took place. Therefore, the researcher fails to conclusively reject the null hypotheses $\mathrm{H}_{\mathrm{o}} 1 \& \mathrm{H}_{\mathrm{o}} 2$.

\section{Conclusion:}

Following major accounting scandals in the US, regulators set stricter rules and requirements for corporate governance in firms, which initiated a chain of improvements in the governance structure of these firms to ensure the transparency and integrity of the financial statements and disclosure. While extant literature has heavily investigated the impact of the 
The Impact of Transitory Losses on Firms' Corporate Governance Structure

Shereen Mohamed Abd El-Fattah Mahmoud

quality of corporate governance on firm performance, very few studies explored the other way around. Therefore, this paper considers how poor firm performance would affect the corporate governance structure of firms.

This research paper examines the occurrence of a transitory loss and its impact on changes made to firms' corporate governance structure following the reporting of the loss. The prior academic literature provides evidence on changes occurring to the corporate governance structure of firms following economic crises and major accounting shocks such as fraud or financial restatements.

In order to answer the research questions and examine the hypotheses, the analysis is based on a sample of transitory loss firms listed in the Egyptian Stock Exchange (EGX) over the period from 2014 to 2017. The transitory loss firms are firms which unexpectedly report a net loss in a year that is preceded and followed by at least two consecutive years of reporting profits. A matched sample of profit firms, which incurred no losses, based on industry and size is also collected in order to isolate the loss event and control for other industry and firm-size characteristics.

To examine the two hypotheses, confirmatory factor analysis of two internal corporate governance mechanisms is done to combine $\mathrm{CG}$ proxies into two general constructs: 
The Impact of Transitory Losses on Firms' Corporate Governance Structure

Shereen Mohamed Abd El-Fattah Mahmoud

board composition and ownership structure. The analysis is then followed by a multiple DID regression analysis to test the response of CG constructs to the transitory loss situation in the loss sample with respect to the profit sample. The findings of this research paper are as follows:

Transitory loss is found to have a significant positive impact on changes occurring in the board composition and ownership structure of loss firms, but those changes aren't significantly different from changes in the structure of profit firms, which leads the researcher to believe that although transitory loss was indeed a factor in applying modifications to the corporate governance structure of loss firms, it seems that it was not the only factor. The researcher is unable to conclusively reject the null hypotheses $\mathrm{H}_{\mathrm{o}} 1$ and $\mathrm{H}_{\mathrm{o}} 2$.

\section{References:}

Alarussi, A. S., \& Alhaderi, S. M. (2018). Factors affecting profitability in Malaysia. Journal of Economic Studies. 45(3), 442-458.

Alfraih, M.M. (2017). Choosing an external auditor: does the composition of boards of directors matter?. International Journal of Law and Management, 59(3), 394-412.

Arora, A., \& Sharma, C. (2015). Impact of Firm Performance on Board Characteristics: Empirical Evidence from India. IIM Kozhikode Society \& Management Review, 4(1), 53-70. 
The Impact of Transitory Losses on Firms' Corporate Governance Structure Shereen Mohamed Abd El-Fattah Mahmoud

Baker, H., \& Powell, G. (2009). Management Views on Corporate governance and firm performance. Advances in Financial Economics, $13,83-118$.

Beasley, M. S., Carcello, J. V., Hermanson, D. R., \& Neal, T. L. (2010). Fraudulent Financial Reporting: 1998-2007. An Analysis of US Public Companies. Committee of Sponsoring Organizations of the Treadway Commission, Durham, North Carolina. available from: http://www.coso.org/.

Damak, S. T. (2013). The corporate governance mechanisms: evidence from Tunisian banks. Journal of Business and Management, 9(6), 61-68.

El-Diftar, D., Jones, E., Ragheb, M., \& Soliman, M. (2017). Institutional investors and voluntary disclosure and transparency: the case of Egypt. Corporate Governance, 17(1), 134-151.

Eshagniya, A., \& Salehi, M. (2017). The impact of financial restatement on auditor changes: Iranian evidence. Asia Pacific Journal of Innovation and Entrepreneurship, 11(3), 366-390.

Fernández, J. L., Odriozola, M. D., \& Luna, M. (2020). How Corporate Governance Mechanisms of Banks Have Changed After the 2007-08 Financial Crisis. Glob Policy, 11, 52-61.

Ferretti, M., Profumo, G., \& Tutore, I. (2015). Shock events and corporate announcements. Journal of Communication Management, 19(1), 81-101.

Karim, S., Manab, N. A., \& Ismail, R. B. (2019). The dynamic impact of board composition on CSR practices and their mutual effect on organizational returns. Journal of Asia Business Studies, 14(4), 463-479. 
The Impact of Transitory Losses on Firms' Corporate Governance Structure Shereen Mohamed Abd El-Fattah Mahmoud

Khlif, H., Samaha, K., \& Azzam, I. (2015), Disclosure, ownership structure, earnings announcement lag and cost of equity capital in emerging markets: The case of the Egyptian stock exchange. Journal of Applied Accounting Research, 16(1), 28-57.

L'Huillier, B. M. (2014). What does "corporate governance" actually mean?. Corporate Governance: The international journal of business in society, 14(3), 300-319.

Menicucci, E., \& Paolucci, G. (2016). The determinants of bank profitability: empirical evidence from European banking sector. Journal of Financial Reporting and Accounting, 14(1): 86-115.

Mulcahy, M. B. (2014). Room for improvement: the impact of bad losses on board quality. Journal of Applied Accounting Research, 15(3), 255-272.

Mulcahy, M. B., \& Donnelly, R. (2015). Corporate Governance, stickiness and losses. Corporate Governance Journal, 15(3), 391-408.

Nanda, S., \& Panda, A. K. (2018). The determinants of corporate profitability: an investigation of Indian manufacturing firms. International Journal of Emerging Markets, 13(1), 66-86.

Nasir, N. A. B. M., Ali, M. J., \& Ahmed, K. (2019). Corporate governance, board ethnicity and financial statement fraud: evidence from Malaysia. Accounting Research Journal, 32(3), 514-531.

Okhmatovskiy, I., \& Shin, D. (2019). Changing Corporate Governance in Response to Negative Media Reports. Brit J Manage, 30, 169-187.

Srivastava, V., Das, N., \& Pattanayak, J. K. (2018). Corporate governance: mapping the change. International Journal of Law and Management, 60(1), 19-33. 
The Impact of Transitory Losses on Firms' Corporate Governance Structure Shereen Mohamed Abd El-Fattah Mahmoud

Utama, C. A., Utama, S., \& Amarullah, F. (2017). Corporate governance and ownership structure: Indonesia evidence. Corporate Governance, 17(2), 165-191.

Younas, Z., Mahmood, H., \& Saeed, A. (2019). Effect of Firm Performance on Corporate Governance: A Panel Data Analysis. Asian Journal of Empirical Research. 3, 1-8.

Zhou, C. (2019). Effects of ownership structure on the relationship between multinationality and downside risk: Evidence from China. Cross Cultural \& Strategic Management, 26(3), 401-421. 